\title{
The Moderating Role of Access to Financing on the Relationship Between Entrepreneurial Orientation and Performance of Batik Smes
}

\author{
Fitri Lukiastuti \\ Magister Management Department \\ STIE Bank BPD Jawa Tengah \\ Semarang, Indonesia \\ fitri111269@stiebankbpdjateng.ac.id
}

\author{
Agung Hendra Kusuma \\ Accounting Department \\ STIE Bank BPD Jawa Tengah \\ Semarang, Indonesia \\ hendraagung07@gmail.com
}

\begin{abstract}
The main objective of this study is to examine the relationship between entrepreneurial orientation and the performance of batik SMEs, with access to financing as a moderating variable. Using data collected from 41 batik SMEs in the city of Semarang, the study used hierarchical moderated regression analysis with $P L S$ which was used to test the hypothesis. The statistical results lead to the conclusion that: the variable dimensions of entrepreneurial orientation (innovation, risk taking and proactivity) have a significant positive relationship with the performance of SMEs, but the variable access to finance is unable to moderate this relationship. The implication of this finding is that financial institutions and the government need to increase their role to encourage the improvement of the performance of batik SMEs in the city of Semarang in terms of providing information, market access, capital, and training needs so that they can become a reference for determining the development strategy of batik SMEs in the future. From the batik entrepreneurs or SMEs itself, this research can be used as a guide for improving business performance through entrepreneurial-oriented behavior.
\end{abstract}

Keywords: innovation, risk taking, proactive, entrepreneurial orientation, access to finance, performance of batik SMEs

\section{INTRODUCTION}

Small and Medium Enterprises (SMEs) in Indonesia, especially in Central Java, achieved encouraging growth in the 2018-2019 Q1 period, namely 143,738 in 2018 and 147,133 in 2019 Q1 or experienced an increase in growth of $9.86 \%$ percent. In addition, SMEs are able to absorb a workforce of 1,043,320 in 2018 and an increase of 1,094,944 in 2019 Q1 [1]. This means that SMEs have quite broad implications when their existence is maximized. Besides being able to absorb more workers than large industries, SMEs can be a tool to alleviate poverty.

There are a number of challenges that affect the performance of SMEs especially in developing countries. Oreoluwa [2] identified financial support as one of the main factors responsible for the failure of SMEs in Nigeria, Ngek [3] said that SMEs in South Africa are not developing, but the failure rate of SMEs in Malaysia is that $60 \%$ of existing SMEs face problems to survive. as a competitive company in the market [4]. For this situation a strategic orientation will be able to increase the success of SMEs and to build the company's competitive advantage which leads to better performance. According to [5], understanding the influence of entrepreneurial orientation and market orientation on the performance of SMEs, especially in developing countries, is very important because it can increase better performance. In addition, access to finance is the lifeblood for business firms to prosper by helping them to exploit growth and investment opportunities [6]; [7]. Therefore, entrepreneurial orientation and access to finance can be seen as important resources for SMEs to improve their performance.

Strategic orientation can affect the performance of SMEs. For example, [5] found a positive relationship between entrepreneurial orientation, market orientation and learning orientation on SME performance. Several studies have found a significant relationship between entrepreneurial orientation and company performance [8]; [9]. In contrast, [10] did not find a significant relationship between entrepreneurial orientation and performance. Many studies reveal a significant effect of market orientation on company performance [11]; [12]. In contrast, a study shows orientation has a negative effect on firm performance [13]

Baron and Kenny [14] stated that the moderating variable is closely related to the inconclusive relationship between the independent variable and the dependent variable and there may be some moderating variables that have not been investigated. According to a resource-based view (RBV), access to finance is the basic engine of a company that leads to company growth [15]. Several studies investigated the role of access moderation to finance company performance ([16], [17]).

In the small handicraft industry, SMEs are facing problems, especially craftsmen, including the marketing problem of Semarang Batik where the wider community is not aware of Semarang Batik making it less desirable, the problem of limited human resources that makes Semarang Batik not developed properly and the problem of lack of capital. where Semarang Batik craftsmen have not received capital assistance from the Semarang City Government. According to [18], the limited sources of financing faced by SMEs, especially from formal financial institutions such as banking, leasing or pawnshops, are the reason why SMEs tend to depend on informal financing.

The problems faced by SMEs related to access to finance are the lack of compatibility (the occurrence of mismatches) between available funds and funds that can be 
accessed by SMEs, there is no systematic approach in financing SMEs, transaction costs high credit, which is caused by a complicated credit procedure that takes up a lot of time while the amount of credit disbursed is very small. Lack of access to formal sources of funds, either due to the absence of remote banks or the unavailability of adequate information, high credit interest rates for investment and working capital and the large number of SMEs that are not yet bankable, either due to lack of financial management transparency and lack of managerial and financial skills. Based on these problems, the following research questions were asked: How does the influence of entrepreneurial orientation (innovativeness, risk taking, and proactiveness) affect SME performance which is moderated by access to finance.

\section{THEORY REVIEW AND HYPOTHESIS DEVELOPMENT}

\section{A. Theory Review}

\section{Resource Based View and Competitiveness}

According to the RBV perspective [19], differences in company performance are mainly caused by factors of uniqueness of company resources and capabilities, not due to industrial structural characteristics. In the context of RBV, company resources include all assets, capabilities, competencies, organizational processes, company attributes, information, knowledge and others that are controlled by the company so that the company can implement strategies to increase efficiency and effectiveness [20]. According to [21] company resources can be classified into three categories, namely: physical capital resources, human capital resources and organizational capital resources. Meanwhile, according to [22] states that resources can be distinguished as tangible (form) and intangible (intangible).

A company will has a sustainable competitive advantage if the company does not implement a value creation strategy simultaneously with existing or potential competitors and if other companies are unable to imitate the advantages of the said strategy [21]. Barney further underlined that in order to create a sustainable competitive advantage, companies depend on strategic resources (strategic assets) which have the characteristics: valuable, rare, imperfectly imitable and not. replaceable (non-subtitutiable) - known as the VRIN conditions [21].

\section{Entrepreneurial Orientaion and SMEs Performance}

Entrepreneurial orientation has become a central concept in the entrepreneurial domain that has received a large amount of theoretical and empirical attention [23]. entrepreneurial orientation refers to the strategy-making process that provides the basis for the organization for entrepreneurial decisions and actions (eg, [24]; [25]). The entrepreneurial orientation dimension can be derived from a review and integration of the strategy and entrepreneurship literature (eg, [26].[27]; [28]; [29]). The entrepreneurial orientation dimension has been identified and used consistently in the literature: innovation, risk-taking, and proactive and competitive aggressiveness, autonomy, and competitive energy.
It is widely accepted in the literature that entrepreneurial orientation is positively related to firm performance (eg [30]). Usually empirical and theoretical research shows that an increase in firm entrepreneurial orientation is positively related to financial performance ([31]; [27]; [32]). Several studies have found that businesses that adopt an entrepreneurial orientation perform better (eg, [25]; [25]; [33]; [34]).

\section{Entrepreneurial Orientation and Access to Finance}

It is known that leverage affects the financial risk for the company in relation to the adequacy of the return on the company's assets compared to the cost of debt. However, the empirical literature on the impact of debt on company performance is inconclusive [35], with several studies finding negative impacts ([36]; [37]) while other accounting for the effect of increasing leverage performance ([38]; [39]). Given that high levels of entrepreneurial orientation strengthen the ability to engage in strategic planning, identify new customer needs and opportunities ([40]) and that the use of leverage may have an impact on performance, access to debt financing can play a moderating variable role, reinforcing the relationship between entrepreneurial orientation and SME performance. We can therefore assume that access to debt financing moderates the relationship between entrepreneurial orientation and firm performance.

\section{B. Hypothesis Development}

\section{The Effect of Innovativeness on Performance of SMEs}

Innovation plays the most important role in improving company performance ([41], [42], [43], [44], [45], [46], [47] and [48]. Innovation is an activity to introduce new ways of product, service, production, marketing and administration, which are difficult to imitate ([49]). Product innovation involves increasing customer benefits for functional or other improvements in a product or service ([50]). In addition, process innovation refers to doing business in new and innovative ways [51]. Organizational innovation is defined as an introduction to new business practices, workplace regulations, decision making, and new ways of dealing with external relations [52].

Studies show that the company's innovative performance [53] has a positive and significant effect on the growth of SMEs. Thus, a culture of innovation has been considered a pre-condition for enhancing organizational, marketing, and managerial entrepreneurship in a competitive market [54]. [55] states that innovation is needed to make a company different, so as to achieve a competitive advantage. The innovative capabilities of companies and individuals in the company have a definite causal relationship with SME performance [56]. Innovative capabilities have a direct and positive impact on company performance results [57]. Thus, this study believes that the level of innovation in an organization is an important determinant of marketing performance [58]. Based on this description, the first hypothesis is proposed as follows:

$\mathrm{H} 1$ : Innovation (product, process, organization and marketing) has a positive influence on the performance of SMEs 


\section{The Effect of Risk Taking on Performance of SMEs}

[59] argue that in a business environment that is considered high-risk, few people are willing to try new initiatives. Those who are willing to do so are likely to generate more profit, increasing the company's growth, if their business is successful. Thus one would expect a positive relationship between risk taking and firm performance as reported in developed countries [60]. From this background, the second hypothesis can be proposed as follows:

$\mathrm{H} 2$ : Risk taking has a positive effect on the performance of SMEs

\section{The Effect of Proactiveness on Performance of SMEs}

Proactive is the behavior of looking for opportunities, a forward-looking perspective involves introducing new products or services in front of competitors and acting to anticipate future demands to create change and shape the environment ([61]; [62]). [63]support this argument by showing that pro-activeness is a firm's response to addressing an unattended market opportunity. This approach is needed to address needs that customers do not articulate and to gain a competitive advantage. The pro-active behavior thus capitalizing on being the first to seize opportunities, also referred to as first mover advantage [64], is the first to offer valuable products and services to customers, build a company's reputation, and attract and retain customers to continue. buy the products and services offered by them. Proactive behavior can benefit SMEs in developing countries characterized by new opportunities that are emerging and relevant in strategic entrepreneurship. Based on this, the third hypothesis proposed is:

H3: Proactivity has a positive influence on the performance of SMEs.

\section{The Moderation Effect of Access to Finance}

Several literatures suggest that access to finance will encourage the growth of SMEs. Moreira [65] has conducted research to identify the impact on SME growth among 1,327 internet and high-tech businesses in Europe and found that access to finance has a significant influence on SME growth. Also another study investigating the factors that influence the performance of small and micro enterprises by collecting data from 161 companies in Kenya found that access to financial resources significantly affects company performance ([66]). Similarly, [67] who were surveyed on the relationship between access to finance and company growth using data from 201 SMEs in Ghana found that the relationship was significantly positive. In fact, the literature implies that a high level of access to finance can facilitate firms to access important resources, in turn, firms are more likely to achieve growth performance..

Liu [68] show that access to finance significantly moderates the relationship between growth orientation and small business growth in the UK. In addition, Adomako [69] reveal that access to financial capital positively moderates the relationship between financial literacy and firm performance of 198 entrepreneurial companies operating in Ghana. Overall, the availability of financial capital can facilitate a company to improve its performance. However, there is limited research that has investigated the moderating role of access to financial capital on the relationship between strategic orientation and firm performance. It is assumed that access to finance is a potential moderator of the strategic performance-orientation relationship, so the fourth hypothesis proposed is:

$\mathrm{H} 4 \mathrm{a}, \mathrm{b}, \mathrm{c}$ : Access to finance moderates the relationship between entrepreneurial orientation (innovation, risk taking, proactivity) and SMEs performance.

Fig 1. Research Model

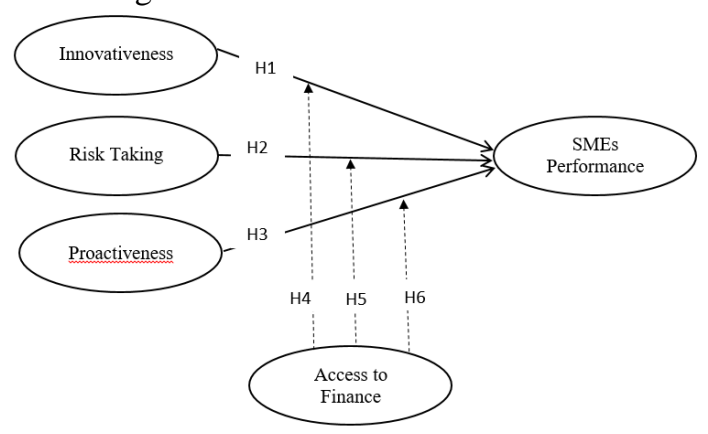

Source: developed for this study, 2020.

\section{RESULT METHOD}

This research approach uses the verification method [70] by conducting causal research to examine the relationship between variables of access to finance, entrepreneurial orientation, and SMEs performance. The population in this study were all 108 batik SME entrepreneurs /craftsmen in the city of Semarang [71]. The number of samples calculated using the Slovin formula is 75 batik SMEs. The sampling method uses random sampling. The analysis tool uses structural equations with the help of the PLS program [72].

The variable access to finance is a moderating variable. The measurement of the entrepreneurial orientation variable consists of eight indicators from [42]. The innovativeness dimension consists of three indicators, namely (1) emphasis on the marketing of existing products, (2) new types of products and services being offered, and (3) radical changes in products and services ([73] \& [25]); as well as a proactive dimension consisting of three indicators from [31] in [74]. SMEs performance measurement consists of four indicators consisting of overall performance (sales growth, ROA, profitability), marketing and sales performance, production performance and R\&D performance ([74]; [75]). Meanwhile, the access to finance variable consists of three indicators from [76]. All research variables were measured using a seven-point Likert scale with a scale of $1=$ strongly disagree and $7=$ strongly agree.

\section{Result AND Discussion}

Data sampling was carried out using random sampling methods and questionnaires were distributed using google form. The questionnaires answered were 41 batik UKM entrepreneurs in the city of Semarang. The owners of batik SMEs in Semarang are dominated by 27 women and 17 
men. The largest number of batik SME entrepreneurs ranged from the 41-50 years age group as many as 19 people $(46.34 \%)$ and the age group over 50 years as many as 4 people $(9.75 \%)$ who were old adults. The youngest age to become a business owner is in the age group 21-30 years as many as 6 people $(14.6 \%)$. The age group of 31-40 years is 11 people $(26.81 \%)$. The largest number of batik entrepreneurs in the city of Semarang have a bachelor's degree as many as 30 people $(73.30 \%)$, followed by entrepreneurs with high school education, namely 6 people $(14.6 \%)$, diploma education ranks third as many as 3 people (1\%) 7,3 and master as many as 2 people $(4,8 \%)$

The average value of the responses of respondents' answers is very high for all variables. Also, the construct value for reliability and validity tests shows that the results have met the standard. The model can be said to be good if the AVE value requirements for each construct are met > 0.50. From the AVE test output in the table, it can be concluded that all the reflective constructs for each variable produce an AVE value $>0.50$. Thus it can be concluded that through the AVE value, the validity of the construct is fulfilled. Based on the R Square output, a value of 0.833 is obtained, which means that the SME performance variable in this study can be explained by the independent variable of $83.3 \%$ while the remaining $16.7 \%$ is explained by other variables outside of this study.

Fig 1. Path Model Diagram

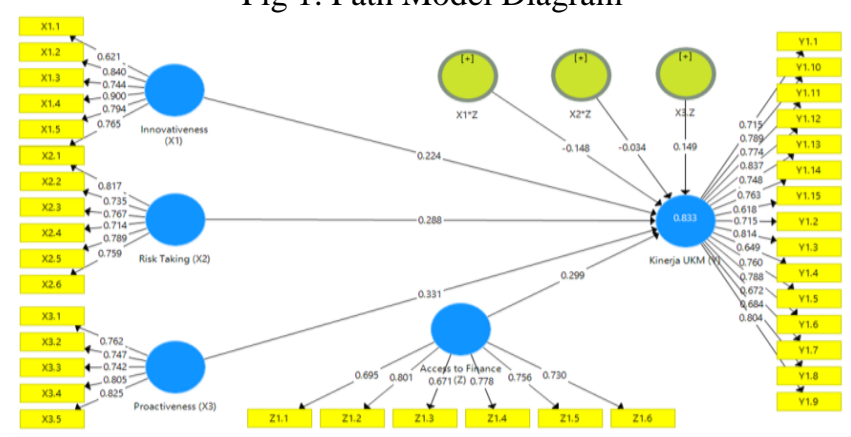

Source: primary data, 2020.

Table 1. Path Coefficients

\begin{tabular}{|l|r|r|r|r|r|}
\hline & $\begin{array}{l}\text { Original } \\
\text { Sample } \\
(\mathrm{O})\end{array}$ & $\begin{array}{l}\text { Sample } \\
\text { Mean } \\
(\mathrm{M})\end{array}$ & $\begin{array}{l}\text { (ST } \\
\text { DEV) }\end{array}$ & $\begin{array}{l}\text { T } \\
\text { Statistics } \\
\text { [O/ } \\
\text { STDEV] })\end{array}$ & $\begin{array}{c}\mathrm{P} \\
\text { Values }\end{array}$ \\
\hline $\mathrm{X} 1 \rightarrow \mathrm{Y}$ & 0.224 & 0.225 & 0.100 & 2.243 & 0.013 \\
\hline $\mathrm{X} 1 * \mathrm{Z} \rightarrow \mathrm{Y}$ & -0.148 & -0.134 & 0.113 & 1.312 & 0.095 \\
\hline $\mathrm{X} 2 \rightarrow \mathrm{Y}$ & 0.288 & 0.277 & 0.101 & 2.837 & 0.002 \\
\hline $\mathrm{X} 2 * \mathrm{Z} \rightarrow \mathrm{Y}$ & -0.034 & 0.052 & 0.205 & 0.166 & 0.434 \\
\hline $\mathrm{X} 3 \rightarrow \mathrm{Y}$ & 0.331 & 0.369 & 0.150 & 2.211 & 0.014 \\
\hline $\mathrm{X} 3 . \mathrm{Z} \rightarrow \mathrm{Y}$ & 0.149 & 0.054 & 0.217 & 0.690 & 0.245 \\
\hline $\mathrm{Z} \rightarrow \mathrm{Y}$ & 0.299 & 0.291 & 0.141 & 2.118 & 0.017 \\
\hline
\end{tabular}

Source : primary data, 2020

\section{The Effect of Innovativeness on Performance of SMEs}

This study proves that innovation affects the performance of SMEs, meaning that the higher the innovation, the higher the performance of the SMEs. The results of this study support the results of research conducted by [53], [54], [77], [56], [78] and [57] which prove that innovation has a positive effect on improving the performance of batik SMEs in Semarang.

Innovation is an effort made by a person by utilizing the mind, the ability of imagination, various stimulants, and the individuals who surround him. The goal is to produce new products, both for himself and the environment. Someone who is successful at making an innovation is someone who is innovative. Indirectly, innovative benefits are bringing something new that can facilitate human life and bring humans into better living conditions. The ability to innovate is a potential ability to place itself in the modernization arena such as the development of new products, technology and other advances that have an impact on competitive advantage over its competitors. This means that SME entrepreneurs need the capacity to create something new in order to gain competitive advantage.

\section{The Effect of Risk Taking on Performance of SMEs}

This study proves that risk taking affects the performance of SMEs, meaning that the higher the risk taking, the higher the performance of the SMEs. To achieve success, of course, there are risks that must be faced. Likewise with entrepreneurship, when someone decides to become an entrepreneur, they must be prepared for the risks that will be faced. This shows that the closer to the peak of success, the greater the risks that must be faced. Entrepreneurs who are not afraid of risk, the greater the success they will get. An entrepreneur must be brave in facing risks. The results of this study support the results of research conducted by [59], [60]. And [61] which prove that risk taking has a positive effect on improving the performance of SMEs.

\section{The Effect of Proactiveness on Performance of SMEs}

This study proves that proactivity has an effect on the performance of SMEs, meaning that the higher the proactive steps, the higher the performance of SMEs. The proactive variable has the greatest and most significant influence on the performance of batik SMEs in Semarang. The results of this study support the results of research conducted by [64], [80], and [79] which prove that proactivity has a positive effect on improving the performance of batik SMEs in Semarang.

The Moderation Effect of Access to Finance on the Relationship of Innovation, Risk Taking, Proactivity and SME Performance.

This hypothesis indicates that access to capital is unable to moderate the relationship between innovation, risk taking, proactivity and the performance of batik SMEs in Semarang. This indicates that although this batik UKM has a fairly good entrepreneurial orientation, it is dealing with a fairly high dynamic environment. Although the access to capital obtained is perceived by UKM to be quite easy, this condition is not directly related to the performance of batik UKM itself.

Although access to capital owned by SMEs is quite easy with the promotion of government programs through various assistance and guidance programs directly from the government or through BUMN and banking, the results show that high environmental dynamics, price competition and market and product diversity can become obstacles for SMEs 
in harness internal strengths to improve performance. Besides that, a very crucial situation is the impact of Covid-19 which affects the income of SMEs. This pandemic caused a decline in performance on the demand side, namely consumption and purchasing power, which then disrupted the production and trade processes. In addition, this situation creates new problems for termination of employment and the threat of nonperforming credit payments. Turnover also decreased by 30 $35 \%$. This is due to the sale of their products that rely on physical meetings or face-to-face meetings between sellers and buyers, so that Covid-19 affects trading activities or activities. Likewise, it has an impact on the problem of distribution of goods and the availability of raw materials and even if there is a price, it is quite high. The results of this study do not support the results of research conducted by [81] and [15] which show that access to finance significantly moderates the relationship between growth orientation and growth of small businesses in the UK. However, in line with the research of [67] and [82].

\section{CONCLUSION AND SugGeSTiON}

\section{Conclussion}

The innovation variable has a positive and significant effect on the performance of batik SMEs in Semarang of 0.224 . The risk-taking variable has a positive and significant effect on the performance of Semarang batik SMEs of 0.288. The proactive variable has a positive and significant influence on the performance of Semarang batik SMEs of 0.331. Access to finance is not able to moderate the relationship between innovation, risk taking, proactivity and performance of batik SMEs in Semarang, however the capital factor is proven to be significant if it is placed as an independent variable. This indicates that the capital factor can directly affect the growth of SMEs and not as a moderator.

\section{Suggestion}

In doing product innovation, the key is never to stop trying. Try to make product innovations by applying a new formula or production method. Semarang batik SME entrepreneurs must open up and join trainings held by the Ministry of Cooperatives and SMEs and companies that pay special attention to SMEs. Apart from actively participating in training, batik SMEs in Semarang must also be active in analyzing competitors' products. This is important to do to analyze prices, business trends, and look for innovative ideas that you can apply to their batik products.

When doing business, batik SME entrepreneurs in Semarang can never eliminate potential risks as a whole but we can reduce negative factors through proper procedures and actions. Therefore, SME management must focus on eliminating the causes of risk that exist in the company, whether due to external or internal influences, so as not to cause problems, especially eliminating the causes of risk that can be controlled.

The next problem with batik SMEs in Semarang lies in the distribution of goods. So far, many SMEs players lack channels in distributing their products. Most of them only focus on distributing goods to a few colleagues and collectors they know only. Of course this way of marketing is still very simple and its reach is not too broad. Batik SME Entrepreneurs in Semarang must be more proactive in participating in product exhibitions held by various government, private and community institutions to expand your market reach. In addition, try to collaborate with various merchants / outlets that can help market batik SME products in their stores. That way, the distribution of these batik products can be wider and reach a wider market as well.

Batik SMEs in Semarang must be able to adapt and maximize various new ways of accessing funding for the continuity of their business, following the COVID-19 pandemic that is still ongoing today. Regarding access to capital, SMEs must be able to find alternative financing so that they are no longer too dependent on government incentives or conventional bank capital. One alternative in the current era is through the option of a digital-based financing platform (fintech), from peer to peer landing to other products that can provide capital solutions.

\section{ACKNOWLEDGMENT}

We would like to thank Khairina Nur Izzati and Pratomo Cahyo Kurniawan for the correction and support for fruitful discussions as well as their support and encouragement. This research is an internal research grant program organized by Research and Community Service Center of STIE Bank BPD Jateng Semarang with research contract number 005/SKP/ P3M/STIEBPD/04/2020.

\section{REFERENCES}

[1] dinkop-umkm.jatengprov.go.id, 2019.

[2] Oreoluwa, Richard. 2011. "Small and Medium Scale Enterprises and Economic Growth in Nigeria: An Assessment of Financing Options." Pakistan Journal of Business and Economic Review 2(1): 78-97.

[3] Ngek, Neneh Brownhilder. 2014. "Determining High Quality SMEs That Significantly Contribute to SME Growth: Regional Evidence from South Africa." Problems and Perspectives in Management 12(4): 253 64.

[4] Khalique, Muhammad, Abu Hassan Isa, Nassir Shaari, and Adel Ageel 2011. "Challenges Faced By The Small And Medium Enterprises (SMEs) in Malaysia : An Intellectual Capital Perspective.” International Journal of Current Research 3(6): 398-401.

[5] Herath, HMA, and R Mahmood. 2014. "Dimensions of Entrepreneurial Self-Efficacy and Firm Performance." Global Journal of Management and Business Research: A Administration and Management 14(4).

[6] Ahmad, S.Z, and A.M.M Arif. 2015. "PROFESSIONAL INSIGHTS Strengthening Access to Finance for Women-Owned SMEs in Developing Countries." Equality, Diversity and Inclusion: An International Journal Vol. 34(No 7): 634-39.

[7] Musamali, Martin M. 2013. "DOES FIRM PROFILE INFLUENCE FINANCIAL ACCESS AMONG SMALL AND MEDIUM ENTERPRISES IN KENYA ? Daniel Kipkirong Tarus.” 3(714): 71423.

[8] Dada, Olufunmilola (Lola), and Anna Watson. 2013. "Entrepreneurial Orientation and the Franchise System: Organisational Antecedents and Performance Outcomes." European Journal of Marketing 47(5): 790812 .

[9] Ferreira, João J., Susana Garrido Azevedo, and Rubén Fernández Ortiz. 2011. "Contribution of Resource-Based View and Entrepreneurial Orientation on Small Firm Growth." Cuadernos de Gestion 11(1): 95116.

[10] Chandrakumara, Anil, Anura De Zoysa, and Athula Manawaduge. 2011 "Effects of the Entrepreneurial and Managerial Orientations of Owner- 
Managers on Company Performance: An Empirical Test in Sri Lanka.” International Journal of Management 28(1): 139-58.

[11] Qu, Riliang, and Zelin Zhang. 2015. "Market Orientation and Business Performance in MNC Foreign Subsidiaries- Moderating Effects of Integration and Responsiveness." Journal of Business Research 68(5): 919-24. http://dx.doi.org/10.1016/j.jbusres.2014.09.018.

[12] Ramayah, T., Nusrah Samat, and May Chiun lo. 2011. "Market Orientation, Service Quality and Organizational Performance in Service Organizations in Malaysia." Asia-Pacific Journal of Business Administration 3(1): 8-27.

[13] Apaydin, F. 2011. "Moderating Effect of Adaptability on the Relationship between Two Forms of Market Orientation and Performance." Interdisciplinary Journal of Contemporary Research in Business 3(2): 1364-77.

[14] Baron, M.R, and D.A Kenny. 1986. "The Moderator-Mediator Variable Distinction in Social Psychological Research: Conceptual, Strategic, and Statistical Considerations." Journal of Personality and Social Psychology 51(6): 1173-82.

[15] Adomako, Samuel, Albert Danso, and John Ofori Damoah. 2016. “The Moderating Influence of Financial Literacy on the Relationship between Access to Finance and Firm Growth in Ghana." Venture Capital 18(1): $43-61$.

[16] Cowling, Marc, and Weixi Liu. 2011. "Business Growth, Access to Finance, and Performance Outcomes in the Recession.” 11(1): 1-39. http://www.ncbi.nlm.nih.gov/pubmed/24670304

[17] Adomako, Samuel, and Albert Danso. 2014. "Financial Literacy and Firm Performance The Moderating Role of Financial Capital Availability and Resource Flexibility."

[18] Rifa'i, Achmad. 2017. "The Role of Islamic People's Financing Banks in Implementing Inclusive Finance Through MSME Financing." Human Falah 4(2): 194-217.

[19] Grant, Robert M. 2001. "The Resource-Based Theory of Competitive Advantage: Implications for Strategy Formulation." California Management Review: 114-35.

[20] Barney, J.B. 2002. Upper Saddle River Gaining and Sustaining Competitive Advantage. NJ: Prentice Hall.

[21] Barney, J. 1991. "Firm Resources and Sustained Competitive Advantage." Journal of Management 17(1): 99-120.

[22] Hoskisson, Robert E., Michael A. Hitt, William P. Wan, and Daphne Yiu. 1999. 25 Journal of Management Theory and Research in Strategic Management: Swings of a Pendulum.

[23] Covin, Jeffrey G., Kimberly M. Green, and Dennis P. Slevin. 2006. "Strategic Process Effects on the Entrepreneurial Orientation-Sales Growth Rate Relationship." Entrepreneurship Theory and Practice 30(1): 57-81.

[24] Lumpkin, G. T., and G.G. Dess. 1996. "CLARIFYING THE ENTREPRENEURIAL ORIENTATION CONSTRUCT AND LINKING IT TO PERFORMANCE." Academy of Management Review 21(1): 135-72.

[25] Wiklund, Johan, and Dean Shepherd. 2005. "Entrepreneurial Orientation and Small Business Performance: A Configurational Approach." Journal of Business Venturing 20(1): 71-91.

[26] Covin, J. G., \& Slevin, D. P. (1991). A conceptual model of entrepreneurship as firm behavior. Entrepreneurship Theory \& Practice, 16, 7-25.

[27] Miller, Danny. 1983. "The Correlates of Entrepreneurship in Three Types of Firms." Management Science 29(7): 770-91.

[28] Miller, Danny, and Peter H. Friesen. 1978. "Archetypes of Strategy Formulation." Management Science 24(9): 921-33.

[29] Venkatraman, N. 1989. "Strategic Orientation of Business Enterprises: The Construct, Dimensionality, and Measurement." Management Science 35(8): 942-62.

[30] O'Shea, Rory P., Thomas J. Allen, Arnaud Chevalier, and Frank Roche. 2005. "Entrepreneurial Orientation, Technology Transfer and Spinoff Performance of U.S. Universities." Research Policy 34(7): 994-1009.

[31] Covin, Jeffrey, G., and P. Slevin, Dennis. 1989. "Strategic Management of Small Firms in Hostile and Benign Environments." Strategic Management Journal 10(1): 75-87.
[32] Zahra, Shaker A.. 1993. "Environment, Corporate Entrepreneurship, and Financial Performance: A Taxonomic Approach.” Journal of Business Venturing 8(4): 319-40.

[33] Zahra, Shaker A. 1991. "Predictors and Financial Outcomes of Corporate Entrepreneurship: An Exploratory Study." Journal of Business Venturing 6(4): 259-85.

[34] Zahra, Shaker A., and Jeffrey G. Covin. 1995. "Contextual Influences on the Corporate Entrepreneurship-Performance Relationship: A Longitudinal Analysis." Journal of Business Venturing 10(1): 43-58

[35] Fatoki, Olawale. 2012. "The Impact of Entrepreneurial Orientation on Access to Debt Finance and Performance of Small and Medium Enterprises in South Africa." Journal of Social Sciences 32(2): 121-31.

[36] Eriotis NP, Franguoli Z, Neokosmides ZV 2002. Profit margin and capital structure: An empirical relationship. J of App Bus Res, 18(2): 8589

[37] Bartholdy J, Mateus C. 2006. Debt and Taxes: Evidence from Bank Financed Small and Medium Enterprises. From http://www.fma.org/Chicago/ papers/tax-payers-wp-version-ja

[38] Negash M 2002. Corporate tax and capital structure: Some evidence and implications. The Invest Analysts J, 56(2): 118-130.

[39] Hadlock CJ, James CM 2002. Do banks provide financial slack? The J of Fin, 57(3): 1383-1419.

[40] Hartsfield S, Johansen D, Knight G. 2008. Entrepreneurial orientation, strategy, marketing capabilities and the performance of born global firms. Int Bus Res Teaching and Prac, 2(1): 12- 38.

[41] Hult, G. T. M., Hurley, R. F., \& Knight, G.A. 2004. Innovativeness: Its antecedents and impact on business performance. Industrial Marketing Management, 33, 429-438.

[42] Dess, G.G. and Lumpkin, G.T. 2005. The Role of Entrepreneuria Orientation in Stimulating Effective Corporate Entrepreneurship Academy of Management Perspectives 19(1):147-156.

[43] Hughes, M. and Morgan, R.E. (2007), "Deconstructing the relationship between entrepreneurial orientation and business performance at the embryonic stage of firm growth", Industrial Marketing Management, Vol. 36 No. 5, pp. 651-661.

[44] Casillas, J. C., \& Moreno, A. M. (2010). The relationship between entrepreneurial orientation and growth: The moderating role of family involvement. Entrepreneurship and Regional Development, 22(3-4), 265-291.

[45] Zarook, T., Rahman, M.M., and Khanam, R. 2013. The Impact of Demographic Factors on Accessing Finance in Libya's SMEs. International Journal of Business and Management; Vol. 8, No. 14; 2013.

[46] Rahman, B.A., Shariff, M.N.M. 2009. Knowledge-based Malaysian GLC: Are they more innovative and performing much better? Malaysian Management Journal, 13( 1\&2), 11- 19

[47] Hameed, I. and Ali, B. (2011). Impact of entrepreneurial orientation, entrepreneurial management and environmental dynamism on firm's financial performance. Journal of Economics and Behavioral Studies, $3(2), 101-114$

[48] Soininen, J., Martikainen, M., Puumalainen, K. and Kyláheiko, K. (2012a). Entrepreneurial orientation: Growth and profitability of Finnish small-and medium-sized enternrises International Journal of Production Economics, 140(2012), 614-621. 